\title{
THE PERFORMANCE OF APPLE CHIPS SUPPLY CHAIN MANAGEMENT AT SMALL INDUSTRY IN BATU CITY
}

\author{
Dwi Retnoningsih ${ }^{1}$ \\ ${ }^{1}$ Lecturer at Socio-Economics Agriculture/Agribusiness Department, Brawijaya University, Indonesia \\ *corresponding author: dwi_sosek@gmail.com
}

\begin{abstract}
Batu City is one of well known cities in East Java Province which is as center of tourism destination and also as center of apple production. There is growing small scale industry related to apple processed products, such as apple chips. In an effort to support the supply of raw materials and production planning, it is necessary to know the achievement of supply chain performance in a small industry of apples chips in Batu City. The method used is qualitative analysis to know the system of raw material inventory control and production planning system applied and analyze the performance of supply chain management, supply chain mapping with SCOR (Supply Chain Operations Reference) method, measurement of supply chain performance by using measured performance attribute that is Supply Chain Reliability, Supply Chain Responsiveness and Supply Chain Agility with performance metrics of Perfect Order Fulfillment (POF), Order Fulfillment Cycle Time (OFCT), Upside Supply Chain Flexibility, Upside Supply Chain Adaptability and Downside Supply Chain Adaptability. The results of this study indicate that the system of raw material inventory control and production planning system have been applied. Supply chain mapping, performance measurement of supply chain management need to be developed more to improve supply chain management performance in the small industry apple chips in Batu City.
\end{abstract}

Keywords: organic paddy, technical efficiency, Tobit regression

\section{INTRODUCTION}

Batu is an urban area of agroindustry with apples as its dominant commodity. Located 15 kilometers west of Malang City at an altitude of 6801.200 meters above sea level, this city is very suitable as a place of various commodities of subtropical plants, one of which is the apple plant. Apple is one of the commodities ofa profitable development prospect. Data of theAgriculture Office of Batu in 2010 showed that the productivity of apples was $17.05 \mathrm{~kg} /$ tree. With abundant stock available, diversification in the form of apple processed products is increasing.

Many small industries in Batu are processing sub-grade apples into new processed products with added value and higher selling prices. Processed products include apple chips, apple cider, dodol apple, apple vinegar, and apple sauce. One of the processed products becoming the main attraction is apple chips. It is snack food belonging to crackers, Agricultural Socio-Economics Journal having dry and crunchy nature (Sulistyowati, 2004 in Sukardi, 2011). Apple chips are processed food products, made by frying using a certain method, in which apples are thinly sliced and then drained using vacuum frying (Waskitasari, 2011).

According to data of the Industry and Trade Office of Batu in 2016, 112 small industries in Batu use apples as their main raw materials, among which 20 small industries whose products include apple chips and 10 small industries which only produce apple chips. Increased sales of processed apple products happens if the quality of the products is good. The high interest in processed apple products has caused an increase in demand for apples. This makes the high demand for raw material inventory control - there is a need to regulate the provision of raw materials. It is necessary in accordance with the required amount and minimal cost, which includes the problem of purchasing materials, storing and maintaining materials, managing expenditures when

Volume 18, Number 2 (2018): 70-78 
materials are needed, and also maintaining an optimal amount of inventory.

The supply of raw materials must be able to meet the needs of the production plan; yet, the rarely taken into account problem is related to the amount of raw material inventory. This is crucial as errors in determining the amount of investment in inventory will depress the profit; and the vice versa, insufficient raw materials will lead to congestion in the production process leading to losses.

To overcome this, it is necessary to fulfill consumer needs in connection with production management within a company. One of the production management related to the fulfillment of consumer needs in quantity is the existence of production planning. Production planning and control is a process for planning and controlling inputs, conducting processes and producing output from a production system so consumer demand can be met with the right amount, the right time of delivery, and minimum production cost (Shofyan, 2013).

To support the production activities, i.e. to deliver products to end consumers, a supply chain is needed. A supply chain is a network of companies that work together in creating and delivering a product into the hands of end users (Pujawan, 2005). A supply chain concerns on the ongoing relationship of goods, money, and information. Goods generally flow from upstream to downstream, money flows from upstream to downstream, while information flows from upstream to downstream and the other way around (Indrajit and Djokopranoto, 2005). Supply chain management is a key factor to achieve a company's goal of winning competition and improving service as well as profit. In achieving these objectives, the company must be able to improve the performance of the supply chain continuously. The stakeholders in the supply chain include suppliers to end customers.

\section{RESEARCH METHODS}

\section{Location and Time}

The study site is determined purposively, i.e. the small industries processing apple chips in Batu. Batu is famous for its apples, thus many small industries in Batu use apples as raw materials. The study is conducted in 2017.

\section{Sampling}

Respondents in this study are chosen purposively. The population consists of 10 small industries that only produce apple chips. They belong to the category of a small industry as they employ 5-19 people. Out of the 10 small industries, 1 of them is considered able to be a representative and is chosen as the sample.

Information is collected form key informants, i.e. people who have knowledge about the existing process in the supply chain activities. Key informants selected are directors, production managers, and marketing managers involved in the supply chain in a certain company of aplle chips in Batu.

\section{Data Collection}

Data consists of primary data and secondary data. Primary data is taken from research objects which are the result of observations, measurements, and interviews to related parties. Secondary data is obtained from the literature related to research topics.

\section{Data Analysis}

\section{Control System for Raw Material Inventory}

The qualitative descriptive analysis is used to analyze and describe the control system of raw material inventory of the small industry in Batu.

\section{Production Planning System}

The qualitative descriptive analysis is used to analyze and describe the production planning system of the small industry in Batu.

\section{Performance Analysis of Supply Chain \\ Management}

a. SCOR Mapping

Mapping is done through the AS-IS Material Flow Design which shows the supply chain condition, from planning, source, make, delivery, and return processes in the small industry of apple chips.

b. Performance Attribution Calculation

Performance attribution measured are supply chain reliability, supply chain responsiveness, and supply chain agility (flexibility). The calculated performance attribution is the external performance attribution, whereas the internal performance attribution is not mesured due to data limitations. Attribution parameters use the following performance metrics:

1. Supply Chain Reliability

Perfect Order Fulfillment (POF) is used in this stage. POF is defined as the performance of the supply chain in delivering the correct product, to the correct place, at the correct time, in the correct condition and packaging, in the correct quantity, with the correct documentation.. POF is determined by:

$$
\mathrm{POF}=\frac{\text { Total orders }- \text { Damaged orders }}{\text { Total order }} \times 100 \%
$$


2. Supply Chain Responsiveness

Order Fulfillment Cycle Time (OFCT) is used in this stage. This refers to the time between customer order and customer receipt of product or service. It is considered very important by the customer as it represents the total "time waiting" experienced. OFCT rate is measured from the average number of days for goods to be delivered to the customer. OFCT is determined by:

OFCT $=\frac{\text { The actual cycle time for the order is sent }}{\text { The number of order delivered }}$

3. Supply Chain Agility (Flexibility)

Three ways are used in this stage:

a. Upside Supply Chain Flexibility

It refers to the capacity building of a supply chain. In this case, it is defined as the number of days required to achieve an unplanned continuous increase of $20 \%$. The upstream supply chain flexibility is based on the longest time calculation required to achieve continuous unplanned improvement taking into account the source, make, and deliver components.

b. Upside Supply Chain Adaptability (USCA)

It refers to the upstream supply chain adjustment. In this case, the USCA is defined as the maximum increase in the percentage of products with sustainable delivery which can be achieved by taking into account the source, make, and deliver components.

$$
\begin{aligned}
\text { USCA } & =\frac{\text { The number of fulfilled orders }}{\text { The increase in orders }} \\
& x 100 \%
\end{aligned}
$$

c. Downside Supply Chain Adaptability (DSCA)

It refers to the downstream supply chain adjustment. In this case, the DSCA is defined as the percentage of order fulfillment that can be met by the company in case of a decline in the raw material supply chain. Supply chain adaptability is based on the sustainable least amount of calculations that can be achieved by taking into account the source, make, and deliver components.

$$
\begin{aligned}
\text { DSCA }= & \frac{\text { The number of fulfilled orders }}{\text { The decrease in supply of raw materials }} \\
& x 100 \%
\end{aligned}
$$

In the next stage, the results of the calculation of supply chain performance will be analyzed using the inefficiency analysis to find out problems in supply chain of the apple chips industry in Batu. This inefficiency analysis aims to measure the performance of the existing supply chain. After the inefficiency analysis, a best practice analysis follows to realize even better supply chain management. This is adapted to the necessary remedial efforts to overcome the existing problems based on the results of the inefficiency analysis.

\section{RESULTS AND DISCUSSION Control System for Raw Material Inventory}

THE SMALL INDUSTRY orders apples to the farmers in a certain quantity and raw materials arrive within one day after ordering. Raw materials are then processed by THE SMALL INDUSTRY into apple chips. The apples should meet a certain size and maturity level. These fresh apples are directly processed to produce the best chips in terms of the freshness, taste, and texture.

\section{Production Planning System}

Scheduling also applies to production planning. THE SMALL INDUSTRY schedules the purchase of raw materials to avoid shortage of raw materials. Sales of apple chips increase at certain moments so THE SMALL INDUSTRY has production planning in order to meet the demand.

\section{Performance of Supply Chain Management}

The supply chain consists of farmers as suppliers and the industry as a producer and distributor of apple chips to the store as end users. The small industry has members of supply chain involving several parties in the preparation of raw materials, production process, and product distribution. The chain supply model of the small industry in Batu City can be seen in Figure 1.

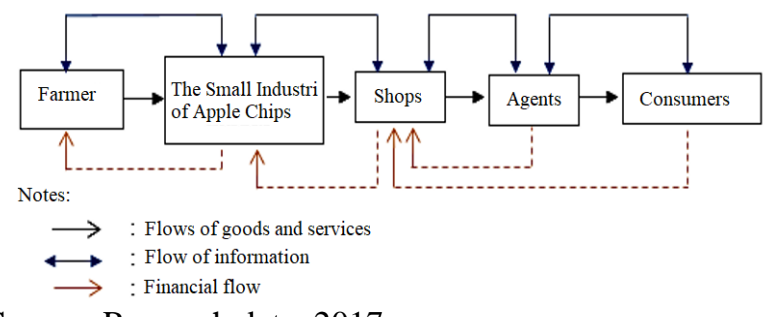

Source: Research data, 2017

Figure 1. The chain supply model of the small industry of apple chips Producer 
The role of each member is as displayed in Table 1. The small industry of apple chips in Batu City has a supply chain which involves various parties from farmers to stores. The supply chain involves the flow of goods or services, financial flows, and the flow of information. The supply chain flow applied is:

1. The flow of goods or services is from suppliers to consumers. The flow of goods in the small industry starts from the small industry orders apples to farmers in certain quantities and raw materials arrive within one day after ordering. Raw materials that have arrived then processed to produce apple chips which are then delivered to the stores. The flow of products from the small industry to the stores is done according to orders. Orders that have been distributed are sometimes unable to meet demand due to limited raw materials and production processes.

Table 1 . The role of each member of the supply chain

\begin{tabular}{|c|c|c|c|}
\hline Role & Member & Process & Activities \\
\hline Supplier & $\begin{array}{l}\text { Apple } \\
\text { farmers }\end{array}$ & Selling & $\begin{array}{l}\text { - Accepting orders of apples from the small industry } \\
\text { - Distributing apples to small industries including the } \\
\text { small industry }\end{array}$ \\
\hline Manufacture & $\begin{array}{l}\text { The small } \\
\text { industry }\end{array}$ & $\begin{array}{l}\text { Purchasing, } \\
\text { production, } \\
\text { marketing }\end{array}$ & $\begin{array}{l}\text { - Purchasing raw materials to farmers } \\
\text { - Processing the raw materials, producing the apple } \\
\text { chips } \\
\text { - Selling the apple chips to stores }\end{array}$ \\
\hline \multirow[t]{3}{*}{ Customer } & Costumers & Purchasing & - Purchasing the apple chips through the stores \\
\hline & Stores & Ordering, selling & $\begin{array}{l}\text { - Ordering apple chips to the small industry } \\
\text { - Selling the apple chips to customers }\end{array}$ \\
\hline & Agencies & Ordering, selling & $\begin{array}{l}\text { - Ordering apple chips to the small industry } \\
\text { - Selling the apple chips to customers }\end{array}$ \\
\hline
\end{tabular}

2. Flow of information in the small industry occurs from upstream to downstream and vice versa, namely:

a. Farmers - the small industry

The flow of information starts from THE SMALL INDUSTRY informs farmers about the amount of raw materials needed, the time to meet the orders, and the criteria of apple fruit to be ordered. Farmers provide information on the number of raw materials that can be met, delivery time, and the amount of money to be paid.

b. The small industry - Agent

The agent provides information to the small industry about the quantity of products to be ordered and the small industry provides information on delivery schedule of product and price to be paid.

c. The small industry - Stores

The stores provide information on sales data and the quantity of products sold to the small industry, and the quantity of new goods needed. The small industry provides information on the delivery of products.

d. Stores - Customers

The consumers ask for the products being sold and the store provides information on the amount to be paid.

3. Financial flow in the supply chain occurs from downstream to upstream. The financial flow begins from the small industry to farmers who make payment on raw materials in accordance with the amount agreed with the cash system.
The agent performs financial flows to the small industry by making payment in accordance with the amount of product ordered and the price with the cash system. The stores make a payment to the small industry once a month and this is to be recorded in the bookkeeping. Consumers make direct payments to agents or stores if consumers purchase and order products.

\section{Metric of the Small Industry Performance}

The quantitative degree in a system, component, or process of a certain size is called a metric. Indicators of a condition or performance management in the supply chain in the industry can be measured using their metrics. This study measures the performance attribution of supply chain including reliability, responsiveness, and flexibility. The metrics used in the SCOR method can be seen in Table 2 . 
Table 2. Metric of the Small Industry Performance in Batu using SCOR

\begin{tabular}{lccc}
\hline \multicolumn{1}{c}{ Metric } & \multicolumn{3}{c}{ Attribution } \\
\cline { 2 - 4 } & Reliability & Responsiveness & Flexibility \\
\hline Perfect Order & $\sqrt{ }$ & \\
Fulfillment & & \\
Order & & \\
Fulfillment & & $\sqrt{ }$ \\
Cycle Time & & \\
Upside Supply & & $\sqrt{ }$ \\
Chain & & \\
Flexibility & & $\sqrt{ }$ \\
Upside Supply & & \\
Chain & & \\
Adaptability & & \\
Downside & & \\
Supply Chain & & \\
Adaptability & & \\
\hline
\end{tabular}

\section{SCOR card, Benchmarking, and Performance Metric Gap}

The specified metrics will then be calculated for its performance. The value obtained based on the calculation is the situation in the small industry in
Batu. The resulting value will then be used as an indicator of performance within the company to determine whether improvement is needed or not.

Benchmarking is a process used to evaluate the various processes that exist within the company in achieving best practice. Benchmarking is a process of achieving the effectiveness of a company. In general, this process is used to find the comparative data from competitors in the field; however, this study does not use competitors as the comparison as it uses target to be achieved by the small industry of apple chips in Batu.

The discussion in the benchmarking process is directed at improving supply chain performance, i.e. its reliability, responsiveness, and flexibility. The difference between the actual condition of the company and the benchmark of the company's target is explained by the performance metrics gap. The gap shows that the company has not achieved the target so improvement must be made. Benchmarking for the small industry of apple chips in Batu is described in Table 3.

Table 3. The Benchmark of Performance of the Small Industry of Apple Chips in Batu from Farmers to Small Industry

\begin{tabular}{llcc}
\hline \multicolumn{1}{c}{$\begin{array}{c}\text { Performance } \\
\text { Attribution }\end{array}$} & \multicolumn{1}{c}{ SCOR Metrics } & Actual & Target \\
\hline Reliability & Perfect Order Fulfillment & $97 \%$ & $100 \%$ \\
Responsiveness & Order Fulfillment Cycle Time & 1 day/200kg & $-3 \%$ \\
Flexibility & Upside Supply Chain Flexibility & 2 days & 1 day/200kg \\
& Upside Supply Chain Adaptability & $50 \%$ & 2 days \\
\hline
\end{tabular}

1. The reliability of the small industry indicates that farmers are able to fulfill orders of apples by $97 \%$, which means very good performance in fulfilling the order. The $3 \%$ difference with the target of $100 \%$ by the small industry is due to smaller sizes of apples or not mature-enough fruit to be used as raw materials. Although the difference is quite small, the small industry asks farmers to improve their performance.

2. The responsiveness on the small industry indicates that farmers are able to fulfill orders of the small industry by 200 kilograms in a day. The time is in accordance with the target of the small industry in fulfilling the order of apples.

3. The flexibility of the small industry in upstream supply chain metrics shows that farmers are able to fulfill unplanned raw material orders in 2 days - this is in accordance with the target of the small industry. The flexibility target for industry is 2 days. In the downstream supply chain, farmers are only able to meet $50 \%$ of the total demand of unplanned orders. The benchmarking results are presented in Table 4.

Table 4. The Benchmark of Performance of the Small Industry of Apple Chips in Batu from the small industry to Stores

\begin{tabular}{|c|c|c|c|c|}
\hline $\begin{array}{l}\text { Performance } \\
\text { Attribution }\end{array}$ & SCOR Metrics & Actual & Target & Gap \\
\hline Reliability & Perfect Order Fulfillment & $98 \%$ & $100 \%$ & $-2 \%$ \\
\hline \multirow[t]{3}{*}{ Flexibility } & Upside Supply Chain Flexibility & 2 days & 1 day & -1 day \\
\hline & Upside Supply Chain Adaptability & $80 \%$ & 100 & $-20 \%$ \\
\hline & $\begin{array}{l}\text { Downside Supply Chain } \\
\text { Adaptability }\end{array}$ & $68 \%$ & $100 \%$ & $-32 \%$ \\
\hline
\end{tabular}


1. The reliability of the small industry apple chips indicates that the industry is able to fulfill orders of apple chips by $98 \%$ to the stores, which means very good performance in fulfilling the order. The $3 \%$ difference with the target of $100 \%$ by the small industry apple chips is due to low quality or damaged apple chips, or not mature-enough fruit to be used as raw materials. It is also caused by the damage in the packaging process. From these results, the small industry apple chips is required to improve its performance in order to be able to meet all orders.

2. The responsiveness of the small industry apple chips indicates that it is able to fulfill 40 kilograms of store orders within 2 days according to the target of the small industry apple chips. The time is in accordance with the target as the location of the stores is quite close to the small industry apple chips - the finished products can be directly sent to the stores. In this case, the small industry apple chips still has to improve its performance in order to avoid delay in delivery process.

3. Related to the flexibility of the small industry apple chips, if there is an increase by $20 \%$ in the orders, it is only able to fulfill the orders within 2 days. This is because the small industry apple chip needs time to meet additional raw materials. In the upstream supply chain, the small industry apple chip is able to ship $80 \%$ of the orders received, out of the target of $100 \%$. This is because the small industry apple chip has enough stock of apple chips in the warehouse. In the downstream supply chain, if there is a decrease in raw materials, the small industry apple chip is able to fulfill order of $68 \%$ from target industry of $100 \%$. In this case, the small industry apple chip still has to improve its performance in order to fulfill all store orders and to give satisfaction to consumers.

\section{Inefficiency Analysis}

The analysis used to examine problems in the supply chain is the inefficiency analysis. The research on the apple chips industry in Batu uses the inefficiency analysis in analyzing supply chain problem. The metrics used in this inefficiency analysis are based on the metrics used in performance from farmers to the industry and from the industry to stores. From the calculation of performance metrics, we will know the problems to analyze. The problem occurs in imperfect order fulfillment, order fulfillment cycle, imperfect upstream supply chain, upstream supply chain adjustment, and downstream supply chain adjustment. Inefficiencies from farmers to the industry and the industry to stores are shown in Table 5 and Table 6.

Table 5. Inefficiencies from Farmers to the Industry

\begin{tabular}{llc}
\hline \multicolumn{1}{c}{ Inefficiency } & Causes & Symbol \\
\hline Imperfect order fulfillment & $\begin{array}{l}\text { Small apples } \\
\text { Not mature apples }\end{array}$ & M2 \\
\hline $\begin{array}{l}\text { Adjustment of the downstream } \\
\text { supply chain }\end{array}$ & Decreased supply of raw materials & M2 \\
\hline
\end{tabular}

Imperfect order fulfillment is because some apples are too small or not mature enough to be processes. These may happen due to:

1. The existence of plant pests and diseases in apples

Pests and diseases make farmers unable to meet orders perfectly. Lack of proper control causes apples to develop disease and be attacked by pests.

2. Too early to harvest

Apples are harvested too early because farmers need to meet the demand for production. However, the apples then cannot be processed as they do not meet the standard set by the industry.
Adjustment of the downstream supply chain happens due to:

1. Decreased supply of raw materials

Pests and diseases lead to decreased supply of apples. Farmers are unable to meet the unplanned orders from the industry.

2. Farmers sell some of the apples to the market Lack of communication between farmers and the industry has caused farmers unable to fulfill the unplanned orders. Farmers need to be informed that their apples must not be sold to the market as those apples are needed by the industry. 
Table 6. Inefficiencies from the Industry (CV AND) to the Stores

\begin{tabular}{llr}
\hline \multicolumn{1}{c}{ Inefficiency } & \multicolumn{1}{c}{ Causes } & Symbol \\
\hline Imperfect order fulfillment & Less availability of raw materials & P2 \\
& Less availability of products & S2 \\
& Trouble in the orders & M2 \\
\hline Upstream supply chain is not & Increase in demand & P1 \\
flexible & Less availability of raw materials & S2 \\
\hline Upstream supply chain & Less availability of raw materials & $\mathrm{S} 2$ \\
adjustment & Less availability of products & $\mathrm{M} 2$ \\
& Problems in delivery & $\mathrm{D} 2$ \\
\hline Downstream supply chain & Decreases supply of apples & $\mathrm{P} 2$ \\
adjustment & Less availability of apples in the warehouse & $\mathrm{P} 3$ \\
& The production process is not maximal & \\
\hline
\end{tabular}

Imperfect order fulfillment cycle is due to:

1. The existence of plant pests and diseases in apples

Pests and diseases cause failure in production. Thus, the raw materials are also decreasing in stock making the industry to experience shortage. This results in the decrease in the products of apple chips.

2. Unavailability of product

Insufficient quantity of raw material causes the industry to not be able to meet the orders. In addition, some problems in the raw materials also become a challenge in the production process that affects the quantity of products resulted.

3. Trouble in the orders

Problems, such as in bad packaging due to lack of quality control, cause the industry to be unable to meet the number of orders.

The upstream supply chain cycle is not flexible due to:

1. Increase in demand

Increase in demand during holidays and Idul Fitri cause the industry to not be able to fulfill orders. On holidays or Idul Fitri, the number of consumers increases as people go on holiday and shop for the apple chips to take home.

2. Less availability of raw materials

The problems related to raw material cause the amount of raw material to decrease. This affects the number of products to be produced.

Downstream supply chain is not flexible due to:

1. Less availability of raw materials

The lack of raw materials happens because the industry has not been able to obtain raw materials incidentally. This is because farmers need time to prepare raw materials ordered by the industry.

2. Less availability of products
The existence of production results is not in accordance with the expected quantity, causing the industry only has limited stock. This causes the industry to not be able to fulfill the order perfectly.

3. Problems in delivery

The damage in packaging is caused by lack of quality control. This makes the products sent to the stores do not match the ones ordered. In addition, the damaged packaging also leads to low quality of packaged products.

Downstream supply chain adjustment is due to:

1. Decreases supply of apples

The damage of apples causes the supply of apples to decrease. In addition, apples harvested to early cause problems in the production. Pests and diseases that attack apples cause the lack of raw material quantity, which finally affects production.

2. Less availability of apples in the warehouse

Stocks stored for too long cause apples to decay. Given the apples cannot be stored for long cause the industry to process apples immediately, so the stock is not damaged. In addition, there are no $f$ apples in the warehouse because the apples are directly processed.

3. The production process is not maximal The damaged apples and the lack of raw materials cause the production to be not optimal.

\section{Best Practice Analysis}

A best practice analysis is an analysis used to provide improvements to existing problems based on the inefficiency analysis conducted on the small scale industry of apple chips. The improvements provided are adjusted based on the inefficiency analysis results.

A best practice analysis refers to efforts to improve supply chain performance associated with performance metrics. The purpose of best practice is 
to improve supply chain performance of the small scale industry of apple chips to be more effective and efficient. The best practice analysis on the small scale industry of apple chips consists of two stages, namely from farmers to the industry and from industry to the stores. The following is the best practice from farmers to the industry:

1. The make process

Best practices that can be applied to overcome the inefficiencies of small and not too mature apples are overcoming pests and diseases and using the appropriate harvesting process. In general, apples can be harvested 4-5 months after flowering, depending on varieties and climates. Manalagi apples can be harvested 114 days after flowers bloom. Harvesting is best done when the plant reaches the physiological ripening level, i.e. the rate at which the fruit has the ability to ripen normally after being harvested. Physiological characteristics of fruit is the size of fruit that looks maximal, the aroma begins to come out, the fruit color looks bright and fresh and feels hard when pressed. In addition, apples can also be harvested in accordance with the period. The apple harvest period is 6 months based on the plant care cycle that has been done.

The following is the best practice from the industry to the stores:

1. Plan process

a. Planning for raw materials

To minimize the shortage of raw materials, CV AND should do the raw material supply planning. Planning raw material demand can be done by determining the Reorder Point (ROP) to control inventory and determine the reservations. The control performed in the ROP is to control and pay attention to the stock at the limit of safety stock. According to Yunarto and Martinuz (2005), safety stock is a parameter that serves to determine the back order. Safety stock is needed to anticipate if there is demand for products that fluctuate during the absence of raw material supply. This can be done continuously to avoid the lack of raw materials by forecasting demand.

b. Increase the supply capacity

To avoid the lack of raw materials, the industry should increase the supply of apples. The addition of this capacity can be done with safety stock which is also a stock of planned additional items. This stock serves as a safety stock to cope with fluctuations in sales forecasts, presence of orders in a short time, and lead time replenishment of inventory (Gaspersz, 2005). Safety stock is also used to anticipate if there is a shortage of supply at a certain time caused by pest attacks or any increase in the price of apples.

\section{Source process}

In the source process formulated by best practice, there are suggestions for improvements to solve the inefficiency problems of the source process. Suggestions for improvement that can be given are:

a. Adding farmers as suppliers

CV AND should add partners, i.e. farmers as suppliers, to meet the supply of apples. Longterm cooperation with apple farmers can increase the supply capacity of raw materials so industries do not experience shortage of raw materials and the production process can run well. Good cooperation can be made by making an agreement or contract to benefit both parties. This is done s the farmers are interested to cooperate with CV AND. Good cooperation can make CV AND obtain continuous supply of raw materials.

b. Expanding the warehouse area

CV AND should make improvements to existing facilities, especially warehouses. CV AND needs to expand the size of the warehouse. Large warehouse can be used to store more raw-materials, so if there is an increase in demand, the industry will be able to meet the demand. In addition, the warehouse can also be used to store stock of products in large quantities.

\section{Make process}

Best practice that can be used in overcoming inefficiency in the make process, related to problems in orders, is by making an order fulfillment strategy. Strategies that can be done are to increase the production capacity and improve supervision on the performance of production employees. Production planning can be done by scheduling. Scheduling is an action to determine the time of each work in the production process. The scheduling system makes it possible to forecast the quantity of products to be produced. Scheduling also aims to produce products that can meet market needs and to minimize the supply of raw materials and products (Madura, 2007). Scheduling includes the scheduling of production and scheduling the purchase of raw materials. CV AND also has to do the scheduling of raw material purchase so the industry does not experience lack of raw 
materials. In addition, increasing the capacity must also be done to anticipate an increase in demand. The addition of this capacity can be done if cooperation with farmers is well established for ease of supply of raw materials. Supervision of employees in the production process is necessary. Its function is to control as well as to know the performance and attitudes of employees. This supervision is done to minimize the presence of reject products.

5. Delivery process

Best practice to overcome the problem of distribution is to evaluate delivery performance, delivery scheduling, and delivery route optimization. Evaluation of delivery performance is seen from the part on time delivery, whether it is correct or not. A very important delivery schedule is made for the delivery to be on time. In addition, the delivery route is based on the shortest distance to shorten the time.

\section{CONCLUSION AND SUGGESTION}

\section{Conclusion}

Based on the findings described in the previous chapters, the following conclusions can be drawn:

1. The small industry of apple chips takes quality very important so it chooses the best raw materials possible and it also directly processes those raw materials.

2. Sales of Apple Chips increased at certain moments so the industry has production planning in order to meet the demand. It requires the more farmers to supply raw materials, or apples, so the production capacity can be increased. To meet its target, it must build a cooperative relationship with farmers in supplying raw materials and agents in selling the products, and thus choosing the right partners becomes very important. In addition, production planning can also be done by scheduling. The industry schedules the purchase of raw materials so the industry does not experience shortage of raw materials. In addition, increasing the capacity must also be done to anticipate an increase in demand.

3. Supply chain management performance has not been effective and efficient so it needs improvement related to performance metrics where the industry requires improvement related to the chain from farmers to industries and industries to stores.

\section{Suggestion}

In order for the performance of the industry to become more efficient and also facing the increasing demand, planning is needed on raw material demand, increasing supply capacity, increasing the number of farmers as supplier, expanding the warehouse area, scheduling and monitoring of production, and evaluation of delivery performance or delivery time so customers are satisfied.

\section{REFERENCES}

Dinas Koperasi Perindustrian dan Perdagangan Kota Batu, 2016. Data Industri Kecil Menengah Kota Batu Tahun 2006-2016. Batu.

Dinas Pertanian Kota Batu, 2010, Laporan Tahunan Dinas Pertanian Kota Batu Tahun 2010, Batu, Malang

Gasperz, V. 2005. Production Planning and Inventory Control. PT Gramedia Pustaka Utama. Jakarta.

Indrajit, Richardus Eko dan Richardus Djokopranoto. 2005. Strategi Manajemen Pembelian dan Supply Chain-Pendekatan Manajemen Pembelian Terkini untuk Menghadapi Persaingan Global. Jakarta: Grasindo.

Madura, J. 2007. Pengantar Bisnis Edisi 4. Salemba Empat . Jakarta

Pujawan, I Nyoman. 2005. Supply Chain Management. Surabaya: Penerbit Gunawidya

Shofyan, Khairani. 2013. Perencanaan dan Pengendalian Produksi. Graha Ilmu. Yogyakarta.

Yunarto, H. I., Martinus, G. S. 2005. Business Concepts Implementation Series in Inventory Management. PT Elex Media Komputindo. Jakarta. 